\title{
PENGARUH KEPEMIMPINAN DAN MOTIVASI KERJA TERHADAP KINERJA PEGAWAI PADA DEPARTEMEN PRODUCTION DI PT CLADTEK BI-METAL MANUFACTURING BATAM
}

\author{
Rahayu Saputri ${ }^{1}$ ) Nur Rahmah Andayani ${ }^{2}$ ) \\ 1) Prodi Administrasi Bisnis Terapan Politeknik Negeri Batam, email: rahayu.saputri12@gmail.com \\ 2) Prodi Administrasi Bisnis Terapan Politeknik Negeri Batam, email: nunun@ polibatam.ac.id
}

\begin{abstract}
Research influence of leadership and work motivation aims to to test the influence of leadership and work motivation on employee performance either partially or simultaneously at PT Cladtek Bi-Metal Manufacturing Batam. Research data collected by using questionnaire method and data analysis used is multiple linear regression analysis using $F$ test and T test. Intake of data by using census, so that data is taken from entire population. Independent variables consist of leadership and work motivation, and the dependent variable is employee performance. This study was conducted by testing the validity and reliability of the instrument, then the data were analyzed and tested using $F$ Test and T Test. The results showed that the leadership of the influential variables are partially negative and insignificant against the performance of employees, and work motivation variables positive and significant effect on performance of employees. While simultaneously variable leadership and motivational variables work a positive and significant effect on performance of employees.
\end{abstract}

Keywords: Leadership, Work Motivation, Employee Performance

\begin{abstract}
Abstrak
Penelitian pengaruh kepemimpinan dan motivasi kerja bertujuan untuk untuk menguji pengaruh kepemimpinan dan motivasi kerja terhadap kinerja pegawai baik secara parsial maupun simultan pada PT Cladtek Bi-Metal Manufacturing Batam. Data penelitian dikumpulkan dengan menggunakan metode kuesioner dan analisis data yang digunakan adalah analisis regresi linier berganda menggunakan uji $\mathrm{F}$ dan uji $\mathrm{T}$.

Pengambilan data dengan menggunakan sensus, sehingga data diambil dari seluruh populasi. Variabel independen terdiri dari kepemimpinan dan motivasi kerja, dan variabel dependennya adalah kinerja pegawai. Penelitian ini dilakukan dengan menguji validitas dan reliabilitas instrument, selanjutnya data dianalisis dan diuji menggunakan Uji F dan Uji t. Hasil penelitian menunjukkan bahwa secara parsial variabel kepemimpinan berpengaruh negatif dan tidak signifikan terhadap kinerja karyawan, dan variabel motivasi kerja berpengaruh positif dan signifikan terhadap kinerja karyawan. Sedangkan secara simultan variabel kepemimpinan dan variabel motivasi kerja berpengaruh positif dan signifikan terhadap kinerja karyawan.
\end{abstract}

Kata kunci : Kepemimpinan, Motivasi Kerja, Kinerja Pegawai

\section{PENDAHULUAN}

\section{Latar Belakang}

Saat ini pertumbuhan dan perkembangan perekonomian di Indonesia semakin pesat salah satunya di wilayah Batam, sehingga persaingan diantara para pengusaha juga semakin ketat. Masing- masing perusahaan saling membenahi perusahaannya dalam berbagai aspek. Oleh karena itu perusahaan diharapkan dapat memenuhi operasional perusahaan seefektif mungkin agar tetap bertahan dari para persaing. Menurut Sumarsono dalam Bahrum (2015) sumber daya manusia mengandung dua pengertian. Pertama, 
adalah usaha kerja atau jasa yang dapat diberikan dalam proses produksi. Dalam hal ini sumber daya manusia mencerminkan kualitas usaha yang diberikan oleh seseorang dalam waktu tertentu untuk menghasilkan barang dan jasa pengertian kedua, sumber daya manusia menyangkut manusia yang mampu bekerja untuk memberikan jasa atau usaha kerja tersebut. Untuk itu sumber daya manusia sebagai aset organisasi perlu dilakukan pengelolaan (manajemen) dengan baik.

Pemimpin adalah orang yang mengemban tugas dan tanggung jawab untuk memimpin dan bisa mempengaruhi orang yang dipimpinnya. Sosok ini mempunyai tugas dan kewajiban untuk memberi perlindungan dan bantuan secara pribadi dan mengelola kegiatan agar dapat mencapai tujuan yang sudah diprogramkan. Setiap pemimpin mempunyai gaya tersendiri dalam memimpin kelompok atau bawahannya. Gaya kepemimpinan seseorang sangat menentukan tingkat keberhasilan kerja dari karyawan yang dipimpinnya, semakin baik gaya kepemimpinan seorang pemimpin, maka semakin tinggi tingkat keberhasilan kerja

pegawainya. Di sini dibutuhkan sosok pemimpin yang dapat berbuat adil, tidak membedakan suku, ras, dan juga tidak mementingkan kepentingan pribadi.

Motivasi yang diberikan oleh pimpinan sangat menentukan, keberhasilan sebuah lembaga atau instansi sangat ditentukan dari motivasi yang diberikan kepada pegawainya. Menurut Hakim dalam Regina (2010) motivasi adalah dorongan, upaya dan keinginan yang ada di dalam diri manusia yang mengaktifkan memberi daya serta mengarahkan perilaku untuk melaksanakan tugas-tugas dengan baik dalam lingkup pekerjaannya. Jika motivasi sangat tidak memuaskan, dan tidak adanya pelatihan kerja yang diberikan oleh instansi, padahal pelatihan kerja merupakan salah satu penunjang kinerja karyawan maka nantinya akan berpengaruh terhadap suksesnya perusahaan. Reward merupakan penghargaan yang diberikan oleh perusahaan untuk karyawan yang berprestasi, agar karyawan lebih meningkatkan kinerjanya. Namun ada beberapa perusahaan tidak memberikan program tersebut kepada karyawan yang berprestasi dikarenakan pelatihan kerja memerlukan dana yang cukup besar.

Menurut Gibson dalam Abdillah (2011), menjelaskan bahwa kinerja organisasi tergantung pada kinerja pegawainya, atau dengan kata lain kinerja pegawai akan memberikan kontribusi pada kinerja organisasi. Apa yang dikemukakan Gibson tersebut dapat diartikan bahwa perilaku anggota organisasi baik secara individu ataupun kelompok dapat memberikan kekuatan atau pengaruh atas kinerja organisasinya. Kinerja merupakan hasil kerja secara kualitas dan kuantitas yang dicapai oleh seorang pegawai dalam melaksanakan tugasnya sesuai dengan tanggung jawab yang diberikan kepadanya. Karyawan merupakan sumber daya yang penting bagi perusahaan karena memiliki bakat, tenaga dan kreatifitas yang sangat dibutuhkan oleh perusahaan untuk mencapai tujuannya. Mengetahui tentang kinerja karyawan merupakan sesuatu yang sangat bermanfaat bagi manajemen perusahaan, karena bisa digunakan untuk

mengevaluasi kerja perusahaan, menentukan arah kebijakan yang akan diambil, dan membuat pengembangan SDM secara optimal demi meraih tujuan perusahaan. Perubahan gaya kepemimpinan dan pemberian motivasi yang tinggi terhadap karyawan dapat memberikan dampak positif bagi kinerja karyawan. Karena tanpa adanya kepemimpinan yang tegas, dan juga motivasi yang kurang akan berpengaruh kepada kinerja karyawan yang tidak optimal. 
PT. Cladtek BI-Metal Manufacturing Batam bergerak di bidang jasa industri untuk berbagai pekerjaan mengenai material logam, khususnya proses Weld Overlay dan Lining pada pipa baja karbon untuk keperluan industri. PT Cladtek BI-

Metal Manufacturing merupakan perusahaan yang memiliki kuota produksi pipa cladding terbesar di Indonesia, dan juga salah satu yang terbesar di dunia. PT Cladtek tersebut memiliki 870 pekerja yang permanent ataupun kontrak. Setiap pekerja memiliki perspektif berbeda-beda mengenai seorang pemimpin. Bagaimana pemimpin tersebut memimpin, bagaimana pemimpin memberi motivasi terhadap karyawannya, bagaimana cara pemimpin dalam menyelesaikan masalah pekerjaan dan bagaimana seorang pemimpin mendengarkan pendapat karyawan dalam mengambil keputusan. Pada kenyataan di PT Cladtek BI-Metal Manufacturing Batam, banyak pekerja yang mengeluh karena pemimpinnya tidak sejalan dengannya, tidak tahan karena perkataan kasarnya dan sebagainya.

\section{Rumusan Masalah}

Berdasarkan latar belakang diatas, maka rumusan masalah dalam penelitian ini adalah:

1. Apakah kepemimpinan berpengaruh positif dan signifikan terhadap kinerja pegawai Departemen Production di PT Cladtek BI-Metal Manufacturing Batam

2. Apakah motivasi kerja berpengaruh positif dan signifikan terhadap kinerja pegawai Production di PT Cladtek BIMetal Manufacturing Batam

3. Apakah kepemimpinan dan motivasi kerja berpengaruh positif dan signifikan secara bersama-sama terhadap kinerja pegawai Production di PT Cladtek BIMetal Manufacturing Batam

\section{Tujuan Penelitian}

Adapun tujuan dari penelitian ini adalah sebagai berikut:

1. Mengetahui apakah kepemimpinan berpengaruh positif dan signifikan terhadap kinerja pegawai Departemen Production di PT Cladtek BI-Metal Manufacturing Batam

2. Mengetahui apakah motivasi kerja berpengaruh positif dan signifikan terhadap kinerja pegawai Production di PT Cladtek BI-Metal Manufacturing Batam

3. Mengetahui apakah kepemimpinan dan motivasi kerja berpengaruh positif dan signifikan secara bersama-sama terhadap kinerja pegawai Production di PT Cladtek BI-Metal Manufacturing Batam

\section{Manfaat Penelitian}

Adapun manfaat dari penelitian ini adalah:

\section{Manfaat Praktis}

Sebagai bahan masukan bagi pimpinan perusahaan, untuk lebih meningkatkan kinerja pegawai dan hal ini dimaksudkan agar karyawan dapat lebih meningkatkan kinerjanya baik untuk saat ini maupun untuk masa yang akan datang.

2. Manfaat Teoritis

a. Penulis dapat menambah pengetahuan secara praktis tentang masalah-masalah yang dihadapi oleh pemerintahan khususnya di PT Cladtek BI-Metal Manufacturing Batam.

b. Hasil penelitian ini diharapkan dapat bermanfaat sebagai bahan ilmiah yang dapat berguna untuk bahan kajian atau informasi bagi pihak-pihak yang membutuhkan. 


\section{KAJIAN PUSTAKA}

\section{Kepemimpinan}

Menurut Inaray dalam Anoraga (2016) kepemimpinan merupakan kekuatan aspirasional, kekuatan semangat, dan kekuatan moral yang kreatif, yang mampu mempengaruhi para anggota untuk mengubah sikap, sehingga mereka menjadi conform dengan keinginan pemimpin. Menurut Robbins dan Judge (2015) kepemimpinan

sebagai kemampuan untuk memengaruhi suatu kelompok menuju pencapaian sebuah visi atau tujuan yang ditetapkan. Organisasi memerlukan

kepemimpinan yang kuat dan manajemen yang kuat untuk efektivitas yang optimal.

Membangun kepemimpinan tidaklah hanya sekedar memiliki keahlian dalam memimpin melainkan memiliki tantangan bagi mereka untuk memimpin para kinerjanya.

\section{Motivasi Kerja}

Motivasi didalam pribadi orang akan berpengaruh langsung terhadap tindakan yang akan dilakukannya, karena motivasi merupakan kekuatan yang ada dalam diri seseorang untuk berbuat sesuatu yang dapat memuaskan keinginannya. Menurut Robbins dan Judge (2015) motivasi didefinisikan sebagai proses yang menjelaskan mengenai kekuatan, arah dan ketentuan seseorang dalam upaya untuk mencapai tujuan. Kekuatan menggambarkan seberapa kerasnya seseorang dalam berusaha. Ketekunan mengukur berapa lama seseorang dapat mempertahankan upayanya. Para individu yang termotivasi akan bertahan cukup lama dengan tugasnya untuk mencapai tujuan mereka.

\section{Kinerja Karyawan}

Kinerja (performance) merupakan prestasi yang dicapai oleh seorang karyawan dalam setiap melakukan pekerjaan atau tugasnya, dengan menggunakan segenap kemampuan pengetahuan dan keahliannya. Bagi karyawan yang berbasis kompetensi,

kinerjanyadiukurberdasarkan

kemampuan,skilldanattitude

(sikapnya) pada setiap saat melaksanakan tugas.

Menurut Dessler dalam Tampi (2014) kinerja karyawan merupakan prestasi kerja, yakni perbandingan antara hasil kerja yang dilihat secara nyata dengan standar kerja yang telah ditetapkan organisasi. Kemudian Robbins dalam Tampi (2014) mendefinisikan kinerja yaitu suatu hasil yang dicapai oleh karyawan dalam pekerjaanya menurut kriteria tertentu yang berlaku untuk suatu pekerjaan.

\section{METODE}

\section{Desain/Jenis Penelitian}

Jenis penelitian yang digunakan adalah penelitian eksplanatory yang bersifat asosiatif, merupakan penelitian yang bertujuan mengetahui hubungan antar dua variabel atau lebih (Sugiyono, 2010). Penelitian tersebut juga menjelaskan antara gaya kepemimpinan dan morivasi terhadap kinerja karyawan. Dalam penelitian jenis ini, hipotesis telah dirumuskan akan diuji untuk mnegetahui adanya pengaruh gaya kepemimpinan dan motivasi terhadap kinerja pegawai di PT Cladtek BI-Metal Manufacturing Batam.

\section{Populasi dan Sampel}

Populasi dari penelitian ini adalah karyawan PT. Cladtek BI-Metal Manufacturing Batam yang bekerja di bagian produksi. Populasi karyawan secara keseluruhan berjumlah 430 karyawan. 
Untuk menentukan ukuran sampel dari suatu populasi, peneliti menggunakan rumus Slovin terlampir dengan jumlah populasi 430 dengan tingkat kesalahan $5 \%$ maka jumlah sampel yang diambil sebanyak 207 karyawan.

\section{Validitas dan Reliabilitas}

Menurut Sugiyono (2014), uji validitas digunakan untuk mengukur sah atau valid tidaknya suatu kuesioner. Suatu kuesioner dikatakan valid jika pertanyaan pada kuesioner mampu untuk mengungkapkan sesuatu yang diukur oleh kuesioner tersebut. Rumus Uji Validitas

$$
R_{x y}=\frac{n\left(\sum X Y\right)-\left(\sum X\right)\left(\sum Y\right)}{\sqrt{\left\{n \sum X^{2}-\left(\sum X\right)^{2}\right\}\left\{n \sum Y^{2}-\left(\sum Y\right)^{2}\right\}}}
$$

Keterangan :

$R_{x y} \quad:$ Menunjukkan indeks korelasi antara 2 variabel yang dikorelasikan

$\mathrm{X} \quad$ : Skor untuk pertanyaan yang dipilih

Y : Skor total yang diperoleh dari seluruh item

$\sum X \quad$ : Jumlah skor dalam distribusi $X$

$\sum Y \quad$ : Jumlah skor dalam distribusi $\mathrm{Y}$

$\sum X^{2} \quad$ Jumlah kuadrat dalam skor distribusi X

$\sum Y^{2} \quad$ : Jumlah kuadrat dalam skor distribusi Y

$N \quad$ : Banyaknya rasponden

Menurut sugiyono (2006) uji reliabilitas adalah serangkaian pengukuran yang memiliki konsistensi bila pengukuran dilakukan dengan alat ukur tersebut dilakukan secara berulang. Rumus Alpha Cronbach digunakan untuk menguji

reliabilitas. Dalam penelitian ini pengukuran reliabilitas dilakukan dengan menggunakan program SPSS 20,0. Suatu keusioner dikatakn reliabel atau handal jika jawaban seseorang terhadap pernyataan adalah konsisten atau stabil dari waktu ke waktu. SPSS memberikan fasilitas untuk mengukur reliabilitas dengan uji statistic Cronbach Alpha (a). Variabel dikatakn reliabel jika memberikan nilai a > 0,60 (Sujarweni, 2008).

$$
r=\left(\frac{k}{k-1}\right)\left(1-\frac{\sum \sigma_{b}^{2}}{\sigma_{+}^{2}}\right)
$$

Keterangan :

$\mathrm{r} \quad$ : Reliabilitas Instrumen

$\mathrm{k}$ : Banyaknya butir pertanyaan

$\sum \sigma_{b}^{2}:$ Jumlah varians butir $\sigma_{t}^{2}$ pertanyaan : Varians total

\section{Metode Analisis Data}

Metode analisis yang digunakan untuk menganalisis data yang telah dikumpulkan adalah sebagai berikut :

\section{Analisis Deskriptif}

Metode analisis deskriptif merupakan cara merumuskan dan menafsirkan data yang ada sehingga memberikan gambaranyangjelasmelalui

pengumpulan, penyusunan dan penganalisisan data, sehingga dapat diketahui gambaran umum dari objek yang diteliti.

\section{Uji Asumsi Klasik}

Uji asumsi klasik digunakan untuk melihat atau menguji suatu model yang termasuk layak atau tidak layak digunakan dalam penelitian. Uji asumsi klasik yang digunakan dalam penelitian ini yaitu uji normalitas data, uji heteroskedastisitas, dan uji multikolineritas.

\section{Analisis Linier Berganda}

Analisis regresi berganda digunakan untuk mengetahui arah hubungan antara variabel independen dengan variabel dependen apakah masingmasing variabel independen berhubungan positif atau negatif dan untuk memprediksi nilai dari variabel dependen apabila nilai variabel independen mengalami kenaikan atau penurunan (Sugiyono, 2012). 


\section{Pengujian Hipotesis}

Untuk pengujian hipotesis yang digunakan dalam penelitian ini yaitu uji parsial, uji simultan, dan koefisien determinasi.

\section{HASIL}

\section{Uji Asumsi Klasik}

a. Normalitas Data

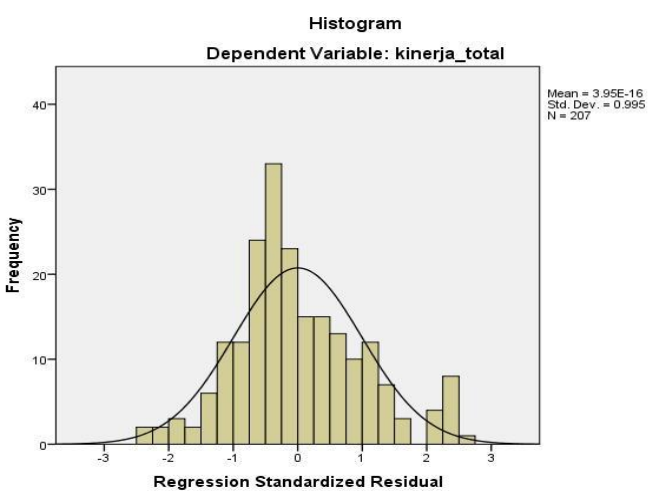

Gambar 1. Uji Normalitas

Berdasarkan gambar di atas dapat di lihat bahwa data menyebar di sekitar garis diagonal dan mengikuti arah diagonal, serta pola distribusi terlihat seperti kurva berbentuk bel. Hal ini menunjukkan bahwa model bersitribusi normal.

Berdasarkan uji normalitas Kolmogorov-Smirnov didapatkan hasil seperti pada table di bawah ini.
Tabel 1. Kolmogrov-Smirnov

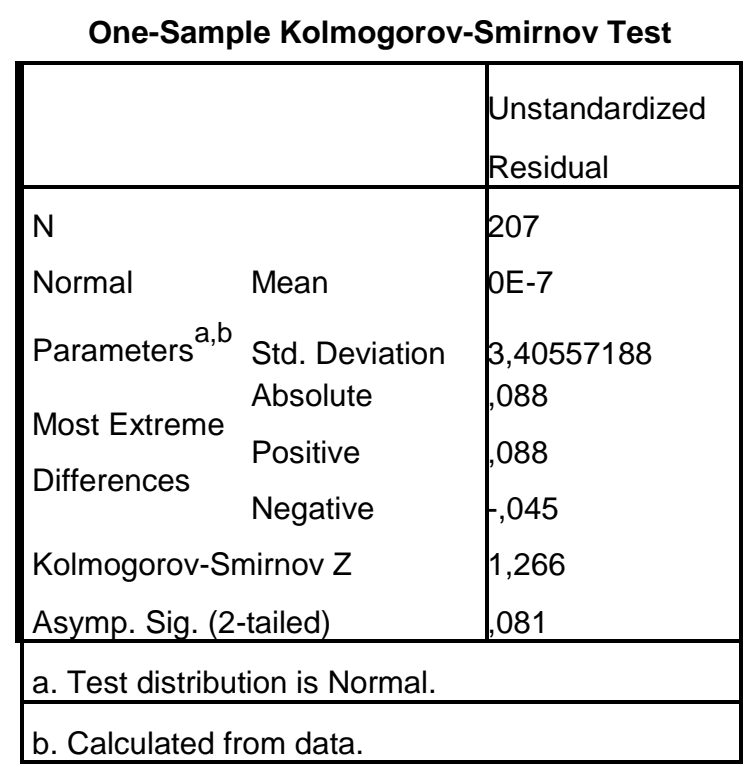

Berdasarkan tabel di atas, disimpulkan bahwa uji normalitas yang menggunakan Kolmogrov-Smirnov sebesar 1,266 dengan tingkat signifikansi $0,081>0.05$ sehingga dapat disimpulkan bahwa residual terdistribusi secara normal.

b. Heteroskedastisitas

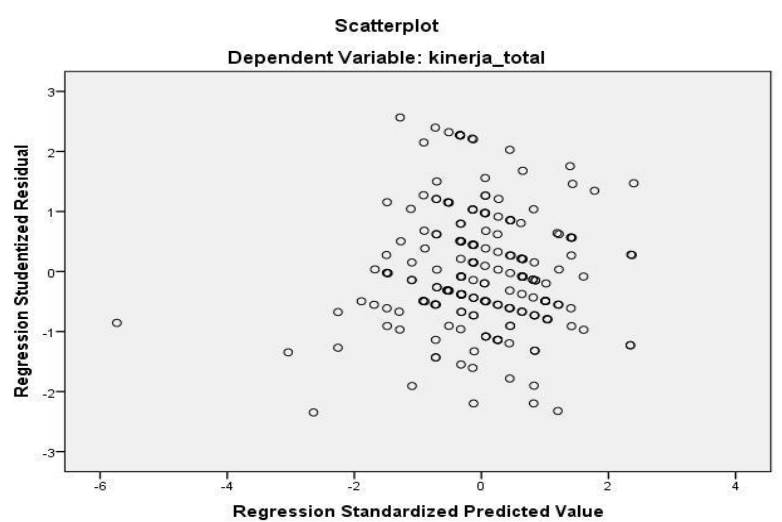

Gambar 2. Uji Heteroskedastisitas

Berdasarkan gambar di atas, hasil pengujian heteroskedastisitas menunjukkan bahwa titik-titik tidak membentuk pola tertentu atau tidak ada pola yang jelas serta titik-titik menyebar di atas dan di bawah angka 0 (nol) pada sumbu Y, maka tidak terjadi heteroskedastisitas. 
Berikut adalah uji heteroskedastisitas menggunakan Uji Glejser SPSS:

\begin{tabular}{|c|c|c|c|c|c|}
\hline \multicolumn{6}{|c|}{ Coefficients $^{\mathrm{a}}$} \\
\hline \multirow[t]{2}{*}{ Model } & \multicolumn{2}{|c|}{$\begin{array}{c}\text { Unstandardiz } \\
\text { ed } \\
\text { Coefficients }\end{array}$} & $\begin{array}{l}\text { Standardized } \\
\text { Coefficients }\end{array}$ & & Sig \\
\hline & $B$ & $\begin{array}{l}\text { Std. } \\
\text { Error }\end{array}$ & Beta & & \\
\hline (Constant) & 4,5 & 1,28 & & 3,54 &, 00 \\
\hline $\begin{array}{l}\text { kepemimpin } \\
\text { an_total }\end{array}$ &, 03 & 01 &,- 13 & $-1,90$ & 05 \\
\hline $\begin{array}{l}\text { motivasi_tot } \\
\text { al }\end{array}$ & 01 & 02 &,- 04 & -62 &, 53 \\
\hline
\end{tabular}

Table 2. Uji Glejser

Berdasarkan output di atas diketahui bahwa nilai signifikansi variabel kepemimpinan (X1) sebesar 0,059 > dari 0,05 artinya tidak terjadi heteroskedastisitas terhadap kinerja karyawan (Y), dan pada variabel motivasi kerja (X2) sebesar 0,535 > dari 0.05 artinya tidak terjadi heteroskedastisitas terhadap kinerja karyawan (Y).

c. Multikolinearitas

\begin{tabular}{l} 
Variabel Tolerance VIF \\
\hline Kepemimpinan $0,9711,030(\mathrm{X} 1)$ \\
Motivasi Kerja $0,9711,030(\mathrm{X} 2)$
\end{tabular}

Tabel 3. Uji Multikolineritas

Dari tabel diatas, terlihat bahwa tidak ada variabel yang memiliki nilai VIF lebih besar dari 10 dan nilai tolerance yang lebih kecil dari 10\%, yang berarti dapat disimpulkan bahwa tidak terdapat multikolineritas antar variabel bebas dalam model regresi.

d. Koefisien Determinasi $\left(\mathrm{R}^{2}\right)$

Nilai kofisien determinasi adalah antara no dan satu . Semakin besar $\mathrm{R}^{2}$ suat variabel independen menunjukkan semakin dominannya

pengaruh variabel independen terhadap variabel dependen dan variabel independen yang mempunyai $\mathrm{R}^{2}$ paling besar menunjukkan pengaruh paling dominan terhadap variabel dependennya.

\section{Analisis Regresi Berganda}

Adapun bentuk model persamaan regresi yang dapat dituliskan dari tabel di atas dalam persamaan regresi sebagai berikut :

$=19,852+0,046 X_{1}+4,278 X_{2}+e$

Gambar 3. Regresi Berganda

Berdasarkan dari hasil data di atas menunjukkan bahwa:

a) Konstanta memiliki nilai sebesar 19,852 yang berarti jika variabel kepemimpinan $\left(\mathrm{X}_{1}\right)$ dan motivasi kerja $\left(\mathrm{X}_{1}\right)$ bernilai 0 , maka variabel kinerja karyawan memiliki nilai sebesar 19,852.

b) Nilai signifikansi variabel kepemimpinan adalah 0,046 (kecil dari alpha 0,05) maka hipotesis ditolak, artinya variabel kepemimpinan tidak berpengaruh terhadap kinerja karyawan.

c) Nilai signifikansi variabel kepemimpinan adalah 4,278 (besar dari alpha 0,05) maka hipotesis ditolak, artinya variabel motivasi kerja berpengaruh terhadap kinerja karyawan.

\section{Uji Hipotesis}




\section{a. Uji T Parsial}

Berdasarkan hasil perhitungan statistik komputer diperoleh data sebagai berikut.

b.

Tabel 4. Uji T (Parsial)

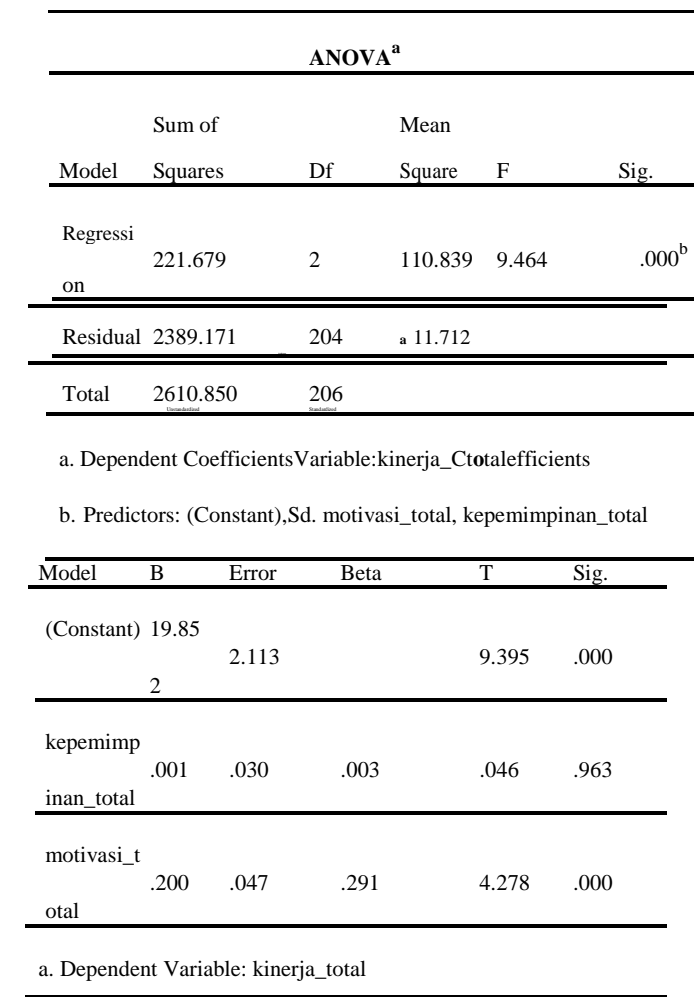

Hasil uji $t$ pada variabel kepemimpinan $\left(\mathrm{X}_{1}\right)$ mempunyai nilai thitung $(0,046)<$ tabel $(1,652357)$ yang berarti tidak terdapat pengaruh secara parsial terhadap variabel kinerja karyawan (Y). Sedangkan hasil uji t pada variabel motivasi kerja $\left(\mathrm{X}_{2}\right)$ mempunyai nilai thitung $(4,278)>$ tabel $(1,652357)$ yang berarti terdapat pengaruh secara parsial terhadap variabel kinerja karyawan (Y).

\section{b. Uji F (Simultans)}

Berdasarkan hasil perhitungan statistik komputer diperoleh data sebagai berikut.
Berdasarkan perhitungan tabel di atas, hasil uji $\mathrm{F}$ diperoleh nilai Fhitung $(9,464)$ $>$ Ftabel $(3,04)$ yang berarti variabel kepemimpinan $\left(\mathrm{X}_{1}\right)$ dan motivasi kerja berpengaruh $\left(\mathrm{X}_{2}\right) \quad$ secara simultan terhadap variabel kinerja karyawan (Y).

\section{c. Koefisien Determinasi $\left(\mathbf{R}^{2}\right)$}

Nilai kofisien determinasi adalah antara no dan satu . Semakin besar $\mathrm{R}^{2}$ suat variabel independen menunjukkan semakin dominannya pengaruh variabel independen terhadap variabel dependen dan variabel independen yang mempunyai $\mathrm{R}^{2}$ paling besar menunjukkan pengaruh paling dominan terhadap variabel dependennya. Berdasarkan hasil perhitungan statistik komputer, diperoleh nilai korelasi ganda sebagai berikut :

Tabel 6. Koefisien Determinasi

\begin{tabular}{|l|l|l|l|}
\hline 2 & Rodel & R Square & $\begin{array}{l}\text { Adjusted R } \\
\text { Square }\end{array}$ \\
\hline 1 & $.291^{\mathrm{a}}$ & .085 & .076 \\
\hline
\end{tabular}

Berdasarkan hasil di atas maka didapat nilai $\mathrm{R}^{2}$ sebesar 0,291, menunjukkan bahwa variabilitas variabel kinerja disebabkan karena adanya variasi variabel kepemimpinan dan variabel motivasi, yang berarti besarnya pengaruh kepemimpinan dan motivasi kerja berpengaruh secara bersama-sama terhadap kinerja pegawai adalah sebesar $29,1 \%$. 
Rahayu \& Nur Rahmah, pengaruh kepemimpinan dan motivasi kerja terhadap kinerja ....

\section{PEMBAHASAN}

Hubungan masing-masing variabel independen $(\mathrm{X})$ dan variabel dependen $(\mathrm{Y})$ dapat dijelaskan sebagai berikut.

1. Dari hasil penelitian pada hipotesis 1 yang menunjukkan bahwa hasil perhitungan $\mathrm{t}$ hitung bernilai 0,046 lebih kecil dari nilai $t$ tabel 1,652 dengan tingkat signifikan t sebesar 0,963 dan nilai alpha 0,05 . Karena nilai signifikan $\mathrm{t}<$ nilai alpha $(0,963<0,05)$ sehingga variabel kepemimpinan secara parsial berpengaruh negatif dan tidak signifikan terhadap variabel kinrja karyawan, dengan demikian $\mathrm{H} 1$ ditolak.

2. Dari hasil penelitian pada hipotesis 2 yang menunjukkan bahwa hasil perhitungan thitung bernilai 4,278 lebih besar dari nilai $t$ tabel 1,652 dengan tingkat signifikan $\mathrm{t}$ sebesar 0,000 dan nilai alpha 0,05 . Karena nilai signifikan $\mathrm{t}<$ nilai alpha $(0,000<0,05)$ sehingga variabel motivasi kerja secara parsial berpengaruh positif dan signifikan terhadap kinerja karyawan, dengan demikian $\mathrm{H} 2$ diterima.

3. Dari hasil penelitian pada hipotesis 3 yang menunjukkan bahwa hasil perhitungan $\mathrm{F}$ hitung bernilai 9,464 lebih besar dari nilai $F$ tabel 3,04 dengan tingkat signifikan $\mathrm{t}$ sebesar 0,000 dan nilai alpha 0,05 . Karena nilai signifikan $\mathrm{t}<$ nilai alpha $(0,000<0,05)$ sehingga semua variabel (kepemimpinan dan motivasi kerja) secara simultan berpengaruh positif dan signifikan terhadap kinerja karyawan, dengan demikian $\mathrm{H} 3$ diterima.

\section{SIMPULAN}

Berdasarkan dari hasil analisis dan pembahasan yang telah diuraikan dalam penelitian mengenai pengaruh kepemimpinan dan motivasi kerja terhadap kinerja pegawai pada PT Cladtek Bi Metal Manufacturing
Batam, maka diperoleh kesimpulan sebagai berikut:

1. Hasil penelitian menunjukkan bahwa variabel kepemimpinan secara parsial berpengaruh negatif dan tidak signifikan terhadap kinerja karyawan.

2. Hasil penelitian menunjukkan bahwa variabel motivasi kerja secara parsial berpengaruh positif dan signifikan terhadap kinerja karyawan.

3. Hasil penelitian menunjukkan bahwa variabel kepemimpinan dan variabel motivasi kerja secara simultan berpengaruh positif terhadap kinerja karyawan.

\section{DAFTAR PUSTAKA}

Abdillah, H. R. (2011). Analisis Pengaruh Gaya Kepemimpinan dan Motivasi Kerja Terhadap Kinerja Pegawai. Jurnal Ekonomi.

Andryani, E. I. (2016). Pengaruh Gaya Kepemimpinan terhadap Kinerja Karyawan. Jurnal Ekonomi Universitas Sanata Dharma Yogyakarta.

Badeni. (2014). Kepemimpinan dan Perilaku Organisasi. Bandung: Alfabeta.

Bahrum, S. P. (2015). Pengaruh Gaya Kepemimpinan dan Motivasi terhadap Kinerja Pegawai. Skripsi.

Dubrin, J. A (2005). Kepemimpinan. Jakarta: Prenada Media.

Fahmi, I. (2014). Manajemen Kepemimpinan. Bandung: Alfabeta. 
Ghozali, I. (2009). Aplikasi Analisis Multivariate dengan Program SPSS. Semarang.

Ghozali, I. (2012). Aplikasi Analisis Multivariate dengan Program IBM SPSS. Yogyakarta: Universitas Ponegoro.

Hartono, J. (2014). Metode Peneltitian Bisnis. Yogyakarta.

Inaray, J. C. (2016). Pengaruh Kepemimpinan dan Motivas Kerja terhadap Kinerja Karyawan. Jurnal Berkala Ilmiah Efisiensi, 3-4.

Mangkunegara, A. A. (2014). Evaluasi Kinerja SDM. Bandung: PT Refika Aditama.

Margaretta, F. (2016). Pengaruh Kualitas

Pelayanan dan Motivasi

Kerja

terhadap Kepuasan Konsumen Melalui Kinerja Karyawan. Jurnal Ekonomi.

P. Robbins, S., \& Judge, T. A. (2015). Perilaku Organisasi. Jakarta Selatan: Salemba 4 Edisi 16.

Rivai, V. (2011). Kepemimpinan dan Perilaku Organisasi. Jakarta.

Siagian, S. P. (2012). Teori Motivasi dan Aplikasinya. Jakarta: Rineka Cipta.

Siregar, S. (2014). Statistik Parametik untuk Penelitian Kuantitatif. Jakarta: Bumi Aksara.

Sugiyono. (2008). Metode Penelitian Bisnis. Bandung : Alfabeta.

----------. (2010). Metode Penelitian Kuantitatif, Kualitatif dan $R \& D$. Bandung: Alfabeta.

----------. $\quad$ (2012). Metode Penelitian
Kuantitatif, Kualitatif dan $R \& D$. Bandung: Alfabeta.

----------. $\quad$ (2014). Metode Penelitian Kuantitatif, Kualitatif dan $R \& D$. Bandung: Alfabeta.

Sukmasari, H. (2011). Pengaruh Kepemimpinan, Motivassi, Insentif, Lingkungan Kerja dan Kepuasan terhadap kinerja pegawai. Jurnal Tesis.

Supartha, W., \& Guterres, L. (2016). Pengaruh Kepemimpinan dan Motivasi Kerja terhadap Kinerja Guru. E-Jurnal Ekonomi dan Bisnis Universitas Udayana Bali.

Syafi'i, L. I., Djumahir, \& dkk. (2015). The Roll Corporate Culture and Employrr Motivation as a Mediating Variable of Leadership Style Related with the Employee Performance.

Tamami, S. (2015). Pengaruh Gaya Kepemimpinan dan Motivasi terhadap Kualitas Pelayanan dan Kinerja Karyawan. E-Journal Administrative.

Tampi, B. (2014). Pengaruh Gaya Kepemimpinan dan Motivasi terhadap Kinerja Karyawann. Journal "Acta Diurna" Volume III. No.4.

Umar, H. (2009). Metode Penelitian untuk Skripsi Dan Tesis Bisnis. Jakarta.

Yani, M. (2012). Manajemen Sumber Daya Manusia. Jakarta: Mitra Wacana Media. Jurnal Procedia - Social and Behavioral Sciences 